\title{
Insurgency and the Shrinking Space for Young Girl Education in the North-East, Nigeria
}

\author{
Osunyikanmi Adebukola Foluke \\ Iwu Nnaoma Hyacinth \\ Department Of Political Science And Public Administration, \\ Adekunle Ajasin University, Akungba, Ondo State, Nigeria
}

Doi: 10.19044/esj.2017.v13n31p114 URL:http://dx.doi.org/10.19044/esj.2017.v13n31p114

\begin{abstract}
Prior the incursion of Boko Haram insurgency into the social nerve of Nigeria, low level of literacy in the North-East geo-political zone of the country was pervasive and has always been a subject of concern to all stakeholders and the federal government.

The Almajiris, a vernacular euphemism for child-beggars, were offered mobile schools. Besides, free and compulsory education were introduced to take school age children off the streets. Of major interest to activists and researcher is the issue of young girl education. The female children had been irresponsibly left behind when western education was introduced to the North. The young girl was neglected for religious, socio-economic and cultural reasons.

Expectations of wholistic benefits, therefore, became high when girls finally have opportunity to access Western education. However, Boko Haram insurgency became a clog in the wheel of progress when they began to kidnap girls and women, destroy school properties, and engaged in suicide bombings. The Chibok girls that were kidnapped from a government secondary school in Borno State was a classic case.

This paper examines the implications of Boko Haram's operations and activities on education in the North-East especially on the fragile status of girl child education. Consideration was also given to the far-reaching effect of the insurgency on the economic lives of the affected children. It concludes with a call for government to embark on strategies that will end insurgency and give the young girl a new lease in life.
\end{abstract}

Keywords: Young girl, education, insurgency, Boko Haram 


\section{Introduction}

Insurgency since 2009 has disrupted educational system in the northeastern region of Nigeria with destructive effects on young girl education. The north-eastern region of Nigeria comprises six states namely Adamawa, Bauchi, Taraba, Gombe, Yobe and Borno State. The region has faced a devastating trend of insurgency, terrorism and brutal killings of innocent citizens perpetrated by Boko Haram. The sect promotes a version of Islam which declares Western education as haram. In other words, it forbids Muslims from taking part in any education, political or social activity associated with Western culture and civilization. The embargo includes but not limited to Western education, voting in elections, and wearing of shirts and trousers. The terrorists continually kidnap schoolgirls, kill students and teachers, and execute Christian and Islamic clerics who oppose their retrogressive doctrine. Massive destruction of school buildings and the use of teenage female suicide bombers are further demonstrations of Boko Haram's strong resentment against Western education.

This massive violence has kept a number of female children out of school. Osunyikanmi (2008) argues that the Northern part of the country is still generally far behind other zones in terms of education while the girls are the most affected. UNICEF reports (2015) confirmed that one in every three primary school children and one in every four junior secondary school children are out of school in the north east. The narratives show that in most traditional African settings, young girl education is dependent largely on encouragement from families, government's provision of school instructional materials and safety of girls in school. The socialization provided by the family is expected to be complemented by government through the provision of safe and secured teaching and learning environment. The frequent cases of kidnappings, abductions, killings and enlisting of girls of school age into bombing operations cripple this lofty aspiration.

This paper interrogates the nexus between insurgency and young girl education in north-eastern Nigeria. The paper examines the origin of insurgency in north-eastern Nigeria, the child right to education in Nigeria, its advantages in nation building, and the effects of insurgency on young girl education in north-eastern Nigeria.

\section{The Origin Of Insurgency In North Eastern Nigeria}

Activities that predate insurgency in the north-eastern Nigeria can be traced to Muhammad Yusuf in 2002, a native of Jakusko in Yobe State. He was the spiritual leader and founder of the Boko Haram sect. Boko Haram officially founded in Maiduguri, the capital city of Borno State, by Muhammed Yusuf is opposed to everything connected with Western education and civilization. Adeyemi (2013) argues that Boko Haram is an 
expression of a global Islamic fundamentalism, notable for two things: internal reform in Islam and the imposition of Islamic rule. The official name of Boko Haram is Jama'atuAhlisSunnaLidda' AwatiWal-Jihad, which in Arabic means "People committed to the propagation of the Prophet's teachings and Jihad", translated by residents in the north-eastern city of Maiduguri, where the group had its headquarters, as "Western education is a sin".

Nigeria since independence in 1960 until 1999, haslargely been governed by military heads of states from Northern extraction who are muslims. During this period, there was a widespread doctrinal belief among the chronic Muslims from the northern extraction to the effect that Christians were heavily proselytising throughout the country, especially in the Meddle Belt region. The response of the northern Muslim political leadership to the spread of Christianity was the deliberate move during the period of 20002003 to impose Sharia Law in 12 out of the 19 northern states in which Islamic religion predominates. This development, to all intent and purposes, brought the dissenting Muslim groups together to promote the spread of Sharia in all the northern states of the country. The narratives show that the imposition of Sharia went down well with the interest of the Islamic political and religious class. However, it was clear that radicals, such as members of the Boko Haram sect were opposed to the slow pace approach adopted by the Islamic and political leadership. As a result, the killing of many Muslim clerics by Boko Haram was perceived as a purificationist agenda with respect to Islam.

In 2004, the group moved to Yobe State where it set up its operational base in a village called Kanamma on the border with Niger Republic. The base was used to launch an armed uprising in September 2004, attacking nearby police station, burning schools with the threat that the war will continue as long as the political and educational systems remained unchanged. According to Adeniyi (2011), the sect renamed the village Afghanistan. The Boko Haram group want Sharia Law to be applied all over the country. They vowed that they would rather have a separate Islamic State carved out of Nigeria where they can practise Islamic religion unhindered. The Federal Government of Nigeria considered the position as a brazen threat to national stability, peace and harmony, by sending police officers to the affected area.

The group launched military operation on July 26, 2009 to create Islamic State. Thus, it kick-started the series of violent attacks on police formations and public buildings in the affected states. The government's response led to the killing of hundreds of the sect members on the streets of Maiduguri and displacing thousands of residents who fled the city. The sect regrouped under a new leader named Abubakar Shekau after their former 
leader Muhammad Yusuf was captured and killed. Adeyemi (2014) notes that from year 2009 and following the assumption of a new leadership headed by Abubakar Shekau, the insurgent group has continued to unleash violence and began what can best be described as the "soft target" capturing of border towns close to the Republics of Cameroon, Chad and Niger, killing unarmed patriotic civilian population of north eastern states in Nigeria, forceful abduction of girls of school age, kidnapping of women, frequent suicide bombing and sporadic shooting in public places.

In September 2010 (coinciding with Ramadan), Boko Haram carried out a prison break in Bauchi State where over 700 inmates, including suspected members of the insurgent group were set free. The group, whose methods of operations include drive-by shootings, suicide bombing and bombing from motorcycles has demonstrated its destructive activities (outside its north-eastern domain) in Katsina and a number of times in Abuja. In 2013, the United States designated Boko Haram a terrorist organisation, expressing that it had developed international links with other terrorist groups, such as al-Qaeda in the Islamic Maghreb, to wage a global jihad. It is important to note that the leader of Boko Haram, Abubakar Shekau formally pledged allegiance to the Islamic State of Iran and Syria. The IS-Iran and Syria accepted the pledge, naming the territory under Boko Haram's control as the Islamic state of West Africa Province and as being part of the global Caliphate it was trying to establish. This development necessitated the United State to include Nigeria as a 'country of interest' in the war against terrorism. The Federal Government also responded to increasing instability in the area by declaring a state of emergency in May 2013 in the three northern states of Borno, Yobe and Adamawa where Boko Haram had strongest operation. However, the deployment of military troops by the Federal Government and the formation of vigilante group in the area caused the sect to retreat to the vast Sambisa forest close to the border with Cameroon from where they launch mass attacks on villages and towns, looting, killing, abducting women and children, and conscripting men and boys into their group.

The abduction in April 2014 of more than 200 schoolgirls by Boko Haram from Chibok town in Borno State and the subsequent declaration of Gwoza as the administrative capital of the caliphate show that the sect is unyielding to counter terrorist measures. The terrorists had boasted that they are in an Islamic Caliphate, stressing that they have nothing to do with the Nigerian state. However, the regional coalition made up of troops from Nigeria, Cameroon, Chad and Niger was able to engage the sect and caused them to retreat to Sambisa Forest. 


\section{The Child Right To Education In Nigeria}

Education is described as the aggregate of all processes through which a child develops abilities, attitudes and other forms of behaviour that are of a positive value to the society. Indeed, it arguably remains one of the most important requirements in the development processes of any nation (Osunyikanmi, 2008). Education enables individuals to acquire appropriate knowledge, values and skills for personal development and contributes meaningfully to the development of society (Fafunwa, 1990). International Covenant on Economic, Social and Cultural Rights (ICESCR, 1966), the Convention on the Right of the Child (CRC, 1989), the African Charter on Human and Peoples' Rights (ACRWC, 1990) and the Protocol to the African Charter on Human and Peoples' Right on the Right of Women in Africa (2003) affirmed education as basic human rights under the Universal Declaration of Human Rights (Isokpan and Durojaye 2016). It is important to note that the International Covenant on Economic, Social and Cultural Rights (ICESCR, 1966) and the Convention on the Rights of the Child (CRC, 1989) recognised and made comprehensive provisions for the rights of the child to education. States are required to make primary education compulsory, free and available to all. States are expected to encourage the development of different forms of secondary education; to offer financial assistance in case of need, as well as to take measures to encourage regular attendance at school and the reduction of dropout rates (Isokpan and Durojaye, 2016). The aim of child education in this regard is to ensure adequate preparation of the child for a responsible life in a free society.

Again, considering the precarious condition of the young girl in accessing education especially in most of the less developed countries of the world, the African Women's Protocol requires states to eliminate all forms of discrimination in the provision of access to education, and to promote the enrolment and retention of girls in schools. The constitution of Nigeria, as amended, (CFRN, 1999) provides that government shall direct its policy towards ensuring the availability of equal and adequate educational opportunities at all levels. By this provision, government at all levels (Federal, State and Local) are required to ensure eradication of illiteracy through free but compulsory universal primary education, free Secondary education, free adult literacy programme and university education. The principal law protecting the Rights of children in Nigeria, the Child's Right Act 2003 (CRA, 2003) in section 15 guarantees the Child's Right to free compulsory education, which the government has a duty to provide (Isokpan and Durojaye, 2016). Also, the Compulsory Free Universal Basic Education Act, 2004 (UBE Act) addresses the issue of access, equality, equity, inclusiveness, the affordability and the quality of basic education. Basic Education, which is contained in the 1977 National Policy on Education 
(NPE) Document (revised in 2013), caters for children including girls. This National Education Policy is described as the foundation upon which the pursuit of higher education is built, and it has since been made the centrepiece of educational policies by successive government in Nigeria. It is important to note that the Universal Basic Education (UBE) scheme, which makes it compulsory for the first nine years of schooling of a child is a strategy adopted by Nigeria towards the fulfilment of the objectives of basic education for all and the Millennium Development Goals (MDGs) with respect to child education. The major aim of this initiative is to eradicate illiteracy, ignorance and poverty in order to facilitate national growth and development. However, Osunyikanmi, (2008) argues that in Nigeria, young girl education is yet to constitute a basic right in spite of government's pronounced commitment.

\section{Young Girl Education And Its Advantages In Nation Building}

Education is the key to nation building and national development; it had existed in the southern part of the country for sixty years before it was introduced to Northern Nigeria (Osunyikanmi, 2008). The Emir of Kano, Mallam Muhammad Sanusi II, emphasized the centrality of young girl education to nation building at the $3^{\text {rd }}$ International conference on Islamic Banking and Finance, organised by the International Institute of Islamic Banking and Finance, Bayero University, Kano on Thursday, $19^{\text {th }}$ January, 2017. He called on wealthy individuals in the north to use their wealth not only in building mosque but to also educate girls and discourage their early marriage. He stated thus:

I am just tired of people coming to me to say I want to build a mosque. You know we keep building mosques and our daughters are illiterates. So my appeal is that if you really want to help Kano, don't come to me with a request to build a N300M mosque because I have enough mosques everywhere. And if I don't have a mosque, I'll build it myself. If you really want to help, go and educate a young girl in the village (Odogwu: The Punch Newspaper 2017).

According to him, over 50 per cent of girls between the age bracket of 18 and 20 were given out in marriage in this part of the country. The worrisome dimension of it was that 75 per cent of them could neither read nor write (Odogwu 2017). Osunyikanmi (2008) had early posited that in the Northern part of the country where Islamic culture is dominant, for example, early marriage of the young girl stands out as a major inhibition to girl child education. Calling for a review of laws to prevent early marriage and encourage young girl education, Sanusi said "'it is not a mere coincidence 
that this is where you have the highest levels of illiteracy, early marriage, divorce and the highest levels of domestic violence', He argued that:

People need to understand that the law has to change. If you look at the medical data on maternal health, girls who get pregnant below the age of 15 are five times as likely to die as girls who get pregnant at the age of 20. Those who get pregnant under 18 are twice as likely to die as those who get pregnant at the age of 20 . So it is important that we look at this issue of early marriage (Odogwu: The Punch Newspaper 2017).

From the foregoing, it is important to emphasise that it should be in the interest of the nation to train a young girl, because when you train a woman, you have trained a nation. Women are generally known to be good managers of resources, especially when they are formally trained. It is therefore, very logical to argue that sustained young girl education will engender better management of family income and by extension, accelerate national income and remove domestic burden from men. Nigerian government and families should therefore, endeavour to ensure that young girl education is given the required attention so that they can contribute their quota to the growth and development of the nation.

One other advantage of young girl education to nation building is the fact that it serves as a major determinant in securing employment for the female and guarantee greater progress in homes. Young girl education has its inherent role in placing peace and freedom in the minds of women. In other word, young girl education is a sine qua non for the political and economic freedom of the womanhood. Arguably, there is a great link between illiteracy and poverty as there is between opulence and education. If a girl is educated, the chances of overcoming economic slavery are very high. In actual sense, it is inconceivable to compare an educated mother with an uneducated mother as the two are in different worlds. It is therefore correct to say that if 70 per cent of the females in a nation have access to quality formal education, the possibility of females overcoming economic slavery is high; and the nation would be on the path to economic prosperity.

In sum, young girl education is one of the best approaches out of the economic dangers that face both nations and families in contemporary time. Educated girls have greater propensity to get empowered, they become successful in life and make meaningful contributions to nation building. Perhaps it is on the basis of the above that the Emir of Kano, Mallam Muhammad Sanusi II, called for the review of existing laws to prevent early marriage and encourage young girl education in the north. 


\section{Effects Of Insurgency On Young Girl Education In North- Eastern Nigeria}

The insurgency in the north-eastern region has a serious impact on the education of children as a vulnerable group. The innocent children are made to pay the ultimate price for a war that is not of their making and miss the beauty of childhood as some of them now grow up among families and communities torn apart by insurgency. Many children from the region are separated from their families and loved ones, left to face the harsh effects of insecurity, hunger and disease as refugees or internally displaced persons. According to Kudirat Initiative for Democracy (KIND, 2014), over 900 schools in the north-east have been burnt and closed, several students and teachers killed and hundreds of girls abducted. Recent studies (Abdulrasheed, Bello, and Adaobi 2014; Joda and Abdulrasheed 2015; Isokpan and Durojaye 2016) on the effects of the insurgency on girls-child education in most of the affected states in north-eastern Nigeria, reveal a very terrible state of insecurity. The studies show that:

1. The insurgency has affected girls' education through mindless attacks on their schools.

2. Frequent abduction of schoolgirls in their dormitory and occasional kidnapping on their ways to school has drastically reduced their attendance in schools.

3. Most teachers and school heads in the region are among the internally displaced persons.

4. Female teachers and schoolgirls were traumatised and afraid of going to school on fear of attacks from the insurgent group.

5. Education planners and inspectors of girls' education programmes cannot conduct periodic check on schools as most education officers in the region are currently out of their states.

The resultant effect of this state of affairs in the north-east is the closure of schools. This has further exacerbated the previous poor rating of the region in terms of access to education. National Population Commission (2014) documented that the north-eastern region rates among the lowest on almost all the formal education indicators. Its rates of attendance, from preprimary school to junior secondary school (JSS), are very low; female primary completion and literacy rates are also much lower than the national average (Sanni, 2015). According to Atiku (2015), existing evidence revealed that $70 \%$ of northerners are illiterates, while ten million Nigerian children are currently out of school. Insecurity in the region has drastically reduced school enrolment more than any other region in the country. Teachers and other stakeholders found it difficult to persuade parents to allow their children to stay in school. Children who go to school now live in perpetual fears while a good number of them drop out of school. Since the 
beginning of 2012, about seventy thousand children have been forced out of schools across communities in Yobe, Kaduna, Adamawa and Borno States (Sanni, 2015) and many teachers have escaped to other states for safety.

The net effect of the foregoing is that numerous girls of school age currently have no access to education in parts of north-eastern Nigeria where schools have been closed for security reasons. In the affected areas where schools still function, children and teachers are often afraid to attend classes. In few schools where there are pupils and teachers, it has been reported that such schools are often overcrowded, understaffed and have insufficient teaching materials; and that because of the violence, many parents are unwilling to enrol their daughters or are withdrawing those already in schools. With the insurgents kidnapping females so that they can be used as human shields and ready tools for suicide bombing, females in the region might be educationally handicapped in contributing their maximum quota to the nation's development (Sanni, 2015).

\section{Data On Schools Attacked By Boko Haram Insurgent Group In Northern Nigeria, 2009 Till December 2014}

\begin{tabular}{|c|c|c|c|c|}
\hline LOCATION & DATE & DESCRIPTION & DEATHS & INJURIES \\
\hline Yobe & June 6, 2009 & $\begin{array}{l}\text { Boko Haram attacked a School in } \\
\text { Yobe }\end{array}$ & & $\begin{array}{c}\text { Injured } 2 \\
\text { teachers }\end{array}$ \\
\hline Yobe & July 27, 2009 & $\begin{array}{c}\text { Boko Haram attacked a police } \\
\text { station, burnt schools and destroyed } \\
\text { churches }\end{array}$ & & \\
\hline Kano & April 29, 2012 & $\begin{array}{l}\text { BokoHaram Bombed Bayero } \\
\text { University }\end{array}$ & 15 & 50 \\
\hline $\begin{array}{l}\text { Maiduguri } \\
\text { (Borno) }\end{array}$ & June 9, 2013 & Boko Haram shooting of children & 9 & \\
\hline Damaturu (Yobe) & June 9,2013 & $\begin{array}{c}\text { Boko Haram killed students and } \\
\text { teachers. }\end{array}$ & 13 & \\
\hline Yobe & July 6, 2013 & Boko Haram school shooting. & $42+$ & \\
\hline Yobe & Sept. 16, 2013 & $\begin{array}{l}\text { Boko Haram bombed Yobe State } \\
\text { School of Agriculture }\end{array}$ & 60 & \\
\hline Yobe & Sept. 29, 2013 & Giyba College massacre & $50+$ & \\
\hline Yobe & Feb. 24, 2014 & $\begin{array}{c}\text { Boko Haram attacked Federal } \\
\text { Government College }\end{array}$ & 59 & \\
\hline $\begin{array}{l}\text { Chibok Town, } \\
\text { Borno } \\
\end{array}$ & April 14,2014 & $\begin{array}{l}\text { Boko Haram abducted } 276 \text { Chibok } \\
\text { School Girls. }\end{array}$ & & \\
\hline Kano & Sept. 17, 2014 & $\begin{array}{c}\text { Boko Haram suicide bomber } \\
\text { bombed Federal College of } \\
\text { Education, Kano }\end{array}$ & 15 & 34 \\
\hline Potiskum (Yobe) & Nov. 10, 2014 & $\begin{array}{l}\text { Boko Haram suicide bomber } \\
\text { bombed Government secondary } \\
\text { school in Potiskum }\end{array}$ & & \\
\hline $\begin{array}{l}\text { Lassa Town } \\
\text { (Borno) }\end{array}$ & Dec. 7, 2014 & $\begin{array}{c}\text { Boko Haram abducted } 20 \text { girls in } \\
\text { Lassa Town, Borno State. }\end{array}$ & & \\
\hline
\end{tabular}

SOURCES: Nigerian Newspapers. 
Insurgency, no doubt, affects the entire Nigerian populace and its neighbouring countries. Terrorism has grave consequence for vulnerable groups. The present state of insecurity in the north-eastern region of Nigeria has been traumatic for children especially school girls. Some of these schoolgirls have been killed by the insurgents; some abducted, forcefully recruited, sexually abused and internally displaced, while others have sought refuge in neighbouring countries. The fundamental human rights of these school girls have been violated as the insurgency has denied them access to good life such as nourishing food, healthcare, infrastructure, security and education. Many of these schoolgirls who are internally displaced are separated from their caring family members thereby suffering from hunger, diseases and emotional trauma. UNICEF (2015) states that following the incessant attacks on schools, school children and teachers (over one million children) have been forced out of school. The acts of killing, kidnapping, abduction, illegal detention, torturing, sexual abuse and forced recruitment of schoolchildren result in violent denial of children's right to education. Their activities include damaging of educational buildings and other facilities, occupying school buildings for military purposes, initiating violent attacks on convoys carrying examination papers, and prevention of repairs, rehabilitation or reconstruction of damaged schools. This dastardly act has an irredeemable effect of depriving millions of children of their right to education; and it denies them the ability to realise their potentials in life. This has a traumatizing effect on children and the Nigerian society.

Today, north-eastern Nigeria has a low literacy level as it has the highest proportion of out-of-school children. The Nigeria Demographic and Health Survey 2013 (NDHS) showed that the north-east had the lowest rate of school attendance in Nigeria, as against the South-eastern region, which had the highest. The survey revealed that Yobe in particular had the worst rate among all the states in Nigeria in terms of school attendance for both male and female children in primary and secondary schools, with just 12 per cent attendance, compared to 75 per cent in Imo State in the South-east. Recent studies conducted in some schools in Damaturu, the capital city of Yobe reveal that the insecurity in the region has caused a further reduction in school attendance. Survey has also shown that Borno State had a devastating experience of the Boko Haram insurgency with huge negative impact on basic education. Young girl education in the north-east which was very poor prior to the insurgency, has worsened as a result of the attacks on schools and kidnapping of female students, with some being turned into suicide bombers. This state of insecurity has forced parents to keep their daughters away from schools. The long-term effects of this in the north-east include: reduced enrolment, permanent drop-out of students and the withdrawal of educational personnel leading to shortage of teachers. 
Insurgency also poses a problem for the states in the affected areas to implement the Education for All (EFA) and Sustainable Development Goals (SDGs) with respect to Universal Basic Education. The exposure of children to traumatic experiences such as killing of loved ones in their presence and displacement has detrimental consequences on their mental and psychological well-being. Isokpan and Durojaye, (2016) show that children are affected by Post-Traumatic Stress Disorder (PTSD) such as irritability, insomnia, sleeping disorder, fear, aggression, confusion, and an inability to concentrate, which greatly affects their ability to have a loving relationship with their families and friends. Their performance in school also suffers. In sum, it is important to note that a society characterised by insurgent activities will not be conducive for social interaction in form of teaching and learning. Insurgency in the north-east is a grave violation of children's rights as it impedes their access to education.

\section{Conclusion}

Insurgency has displaced millions of people in north-eastern Nigeria and led to the closure of hundreds of schools in the area. Young girl education in the north-east which was very poor prior to the insurgency has worsened as a result of the attacks on schools and kidnapping of female students. Some female students have even been turned into suicide bombers. This state of insecurity has forced parents to keep their daughters away from schools. The long-term effects of this in the north-east include: reduction in school enrolment, permanent drop-out of students and the withdrawal of educational personnel. In addition, the crisis has led to shortage of teachers which in turn will weaken the nation's ability to achieve the Sustainable Development Goals (SDGs), Education for All (EFA), as well as Nigeria Vision 2020 programme. As a result of the insurgency in the area, majority of the girls of school age are uneducated and they face limitations inhibiting their contributions to national development. This state of affairs calls for immediate government intervention to end terrorism and insurgent activities. The government must provide an enabling environment for young girl education in the region.

It is important to note the successes recorded by the military but government needs to pursue a more comprehensive strategy that will address the economic and social roots of the crisis. Deliberate measures must be taken to address the prevalence of poverty, unemployment and low level of education among the youths. The youths are potential weapons in the hand of the insurgent group. Government should therefore adopt mass education and literacy programmes in the region as the main tool for empowering the citizenry in general and the young girl in particular. The various levels of government in the region and wealthy individuals should collaborate to 
embark on massive education programmes. The international community and financial institutions should be encouraged to assist in providing adequate fund and expertise that will ensure that government in the region give education the required attention. Government should also make necessary efforts to expose and bring to justice all Boko Haram militants, sponsors and those who are benefiting from the insurgency.

In addition, government should launch an aggressive awareness programme to encourage children especially the young girl to return to school through the provision of scholarship and other incentives. Governments in the region should provide free and compulsory education from primary through university for all girls in the north-eastern region. The religious leaders should play active role in preaching against terrorism. Adequate security must be guaranteed in schools to reassure students and teachers of their safety during school hours. The government must rehabilitate and resettle all internally displaced children. The affected communities should be made safe for the fleeing teachers to return and provide their services for the upliftment of the young girl.

\section{References:}

1. Adeniyi, O. (2011), 'Between Mutallab and Boko Haram'' in Power, Politics and Death: A front-row account of Nigeria Under the late President Yar'Adua', Prestige Imprint, Yaba, Lagos, Nigeria.

2. Adeyemi. K. (2014), The Kano College Blast: The National Newspaper

3. Abdulrasheed O., Bello A., Adaobi O, (2014), Historical Analysis of Boko Haram Insurgency on Educational Management in Northern Nigeria, Global Journal of Arts Humanities and Social Sciences, published By European Centre for Research Training and Development UK (www.eajournals.org)

4. Atiku, A. (2015) " Atiku Abubakar has revealed that $70 \%$ of Northerners are illiterates, while ten million Nigerian children are currently out of school. (Federal Government Neglects Almajiri Schools Naij. Com. 21/01/2015

5. Fafunwa, A.B. (1990) History of Education in Nigeria, George Allen Press, London, UK.

6. Isokpan, A.J and Durojaye E. (2016), 'Impact of the Boko Haram Insurgency on the Child's Right to Education in Nigeria, PER/PELT (19) DOI

7. Joda, F. and Abdulrasheed O. (2015) ''Effects of Insurgency on Girls Education in North-eastern Nigeria', European Journal of Education and Development Psychology, UK, Vol.3, No.1.pp 44-50 
8. Osunyikanmi, A. F. (2008) "Gender Inequality in Nigeria Education sector"' African Journal of Stability and Development, Vol. 2 No. 2

9. Oyeniyi, B. A. (2013), " Boko Haram: One Voice, Multiple Tongues"' in Adeyinka Bankole and Shola J. Omotola (eds), Whither The Nigerian Project? South Africa, JUTA.

10. Oyeniyi, B. A. (2013), "'Boko Haram Terrorists' Menance and Nigeria's National Security' in Toyin Falona and Jane Nana (eds), Social and Religious Movements in Africa, New York, Africa World Press.

11. Oyeniyi, B.A. (2013),', Will Emergency Rule Curb Boko Haram Violence?' Available at http:/dwafrica.ng.com/news Research on Islam and Muslims in Africa, RIMA Policy Paper, Volume 1 (2013)

12. Sanni, O. B. (2015), ''Effects of Insurgency and Challenges on Female's Education in Nigeria', African Journal for the Psychological Study of Social issues, Vol. 18 No. 3, pg 51-57.

13. Kudirat Initiative for Democracy (KIND, 2014), '’Pushing for safe education for Girls in Nigeria', Catapult, New York, NY 11201.

14. NCRM (2014), National Commission for Refugee Management Agency, Abuja, Nigeria.

15. NEMA (2014), National Emergency Management Agency, Abuja, Nigeria.

16. National Population Commission (2014), Basic Education Profile for North-east Nigeria (Adamawa, Bauchi, Borno, Gombe, Taraba, and Yobe States).

17. National Population Commission (2013), Nigeria Demographic and Health Survey

18. UNICEF (2015), Insecurity Threatens Gains in Girls' Education: Parent Unwilling to Enrol Their Daughters in School in the NorthEast.

19. Odogwu, T. 2017. Educate Girls, Stop Building Mosques, Sanusi tells Northerners, The Punch Newspaper January 20. 